\title{
MAIZE ENDOSPERM TISSUE GROWN IN VITRO \\ I. CULTURE REQUIREMENTS ${ }^{1}$
}

\author{
Jacob Straus ${ }^{2}$ and Carl D. LaRue
}

IN RECENT YEARS the number of plant tissue cultures grown in vitro has been greatly increased. Other than the usual callus cultures derived from dicotyledonous plants (Gautheret, 1947a), tissues derived from monocotyledonous plants as well as from the Pinaceae, Ginkgoaceae, Filicinae, and the Lycopodinae have been established in culture.

Curtis and Nichol (1947) obtained cultures of overgrowths produced by orchid embryos grown in vitro. Morel and Wetmore (1951a) were successful in growing callus tissues derived from the tubers of several tropical members of the Araceae. Ball $(1950,1953)$ has described the regeneration of new plants from Sequoia callus as well as the absorption of radioactive isotopes by these same cultures. Lowenberg and Skoog (1952) reported on their success in growing the callus produced by two species of Pinus embryos.

Reports of several tissues derived from unusual morphological sources have also appeared recently in the literature. Thus, the endosperm of maize was first isolated by LaRue as a continuous culture in 1949. Morel and Wetmore (1951b) have grown Osmunda gametophyte callus in vitro. Wetmore and Morel (195la, 1951b) have established tissue cultures derived from the gametophyte of Lycopodium and the female gametophyte of Selaginella. The endosperm of Asimina triloba has been isolated by Lampton (1952) as a continuous tissue culture. Tulecke (1953) reported on the growth of a tissue which arose in in vitro cultures of Ginkgo pollen. This tissue appears to be the most unusual of all plant tissue cultures as it may represent an extended growth of the greatly reduced male gametophyte since the tissue appears to have arisen from the tube cell. Recently LaRue (unpublished) and his students have grown endosperm of Lolium perenne and stem tissues of Cryptomeria japonica, Cupressus funebris, Theobroma cacao and Citrus aurantium as well as tobacco-root tumor tissue.

None of the tissues mentioned in the above paragraph except for Osmunda gametophyte callus and newly cultured maize endosperm have been reported to differentiate any vascular elements or the more

\footnotetext{
1 Received for publication February 8, 1954. Paper No. 1002 from the Department of Botany, University of Michigan.

${ }_{2}^{2}$ American Cancer Society Research Fellow. Present ad. dress: The Biological Laboratories, Harvard University, Cambridge, Mass. Some of the data in this paper were taken from a dissertation by Jacob Straus presented to the Graduate School of the University of Michigan in partial fulfillment of the requirements for the degree of Doctor of Philosophy. Parts of the present work were supported by a research grant to $C$. D. LaRue by the Horace $H$. Rackham Research Fund of the University of Michigan and grateful acknowledgment for this assistance is made.
}

complex tissue systems of roots and shoots. In 1947, LaRue reported the differentiation of several plantlets from maize endosperm tissue recently placed in culture, but since that time no examples of morphological differentiation have been found to occur in these tissue cultures. The tissue has remained homogeneous except for some cytological differentiation which will be reported upon in a subsequent paper.

Tissue cultures composed of one morphological type of tissue and which possess the property of unlimited growth in vitro bear great promise in the study of problems of metabolism and differentiation. For example, in metabolic studies one may be fairly certain that the metabolism under investigation is that of a single tissue type. Similarly, in morphogenetic studies one can be reasonably assured that any differentiation which may occur is due to a manipulation of the environment and not to a purely fortuitous phenomenon.

As the tissue derived from maize endosperm grows rapidly and exhibits the desirable property of infrequent spontaneous morphological differentiation, it was considered to be a likely experimental system to utilize in physiological and morphogenetic studies. Before this can be done, however, it is necessary to determine the chemical and physical environments which will permit optimum growth of the tissue. This paper is a report on the progress of the investigations being carried out to this end.

Materials and Methods. - The tissue used throughout this study is designated as CE Clone 1-C. It was originally isolated by LaRue (1949) from an unidentified strain of maize. The tissue does not grow on a completely synthetic medium and at that time was maintained in culture on White's medium (1943) containing enough filtered tomato juice prepared from whole canned tomatoes to substitute for one-third of the water. On this medium, growth was erratic and unpredictable. When placed on a medium which contained Seitz-filtered yeast extract added to White's basal mineral agar, growth of the tissue was much more uniform.

Initial isolation of the tissue.-Young ears were husked, cut into pieces of convenient size and sur. face sterilized for $20 \mathrm{~min}$. in a solution of 20 per cent Clorox. The tops of the kernels were cut off with a sterile knife. The exposed endosperms were then scooped out and placed on the surface of the nutrient medium. Controlled pollination experiments showed that the optimum age which would give best growth after excision was 12 days postpollination. In attempts to isolate other strains of maize endosperm as tissue cultures, it was found that of 15 varieties tested, only 2, 'Surprise Sweet' 
and 'Black Mexican SWweet,' could be depended upon to give uniform results. It is interesting to note that none of the several waxy or starchy varieties tested gave any growth response.

As the tissue cultures derived from both Surprise Sweet and Black Mexican Sweet grow slowly, it was decided that CE Clone 1-C, despite the lack of knowledge of its genetic origin, would be used in the present series of investigations as its rate of growth is about ten times as rapid as that of either of the other 2 strains.

The medium. - The basal mineral solution used was modified from White's nutrient medium. The medium was modified by the substitution of Nitsch's trace elements (1951) for those used by White and the omission of the organic nutrilites suggested by the latter.

Yeast extract was found to be essential for the growth of the tissue. Difco yeast extract was used and although several different lots of the material were utilized, no apparent differences in growth response were noted which could be attributed to the yeast extract. The extract was sterilized by Seitz-filtration and was added to the previously autoclaved medium.

The solution was solidified with 0.8 per cent agar. Two per cent sucrose was the standard carbon source except where otherwise stated.

The culture vessels were screw-capped vials of approximately $20 \mathrm{ml}$. capacity. Usually about $8 \mathrm{ml}$. of the medium were dispensed into each vial. Cultures were routinely grown in the dark at a temperature of $25^{\circ} \mathrm{C}$. plus or minus $2^{\circ}$.

Preparation of the inocula.-Throughout the entire investigation, 50 replicates were used for each experiment. This number of samples was chosen more or less arbitrarily and was retained because of the easily reproducible results which were obtained with it. Each experiment was repeated at least once so that each figure in the tables and each point on the curves which show a change in weight represent the accumulated changes of at least 100 pieces of tissue.

Pieces of tissue were selected on the basis of color. The tissue assumes a brown color with age, hence, only pieces which were white or light-yellow were chosen from actively growing stock cultures which varied in age from 11-14, days after subculture. Generally, a total of $6-8 \mathrm{~g}$. of tissue was chosen from among several selected cultures, placed in sterile, tared weighing bottles and the weight determined to the nearest $\mathrm{mg}$. on an analytical balance. The material was then distributed as individual pieces of approximately $120 \mathrm{mg}$. each among 50 bottles of medium. At the end of an experiment, the tissue was removed from the culture vials, gently blotted to remove as much excess water and agar as was practicable, and the total weight of the pooled tissue was determined.

To determine the percentage change in dry weight, the tissue was dried in an oven maintained
TABLe 1. Parallel changes in per cent dry weight and per cent total nitrogen in endosperm tissue after growth in vitro

\begin{tabular}{ccc}
\hline \hline $\begin{array}{c}\text { Exp. } \\
\text { No. }\end{array}$ & $\begin{array}{c}\text { Dry wt. } \\
\text { \% change }\end{array}$ & $\begin{array}{c}\text { Total nitrogen } \\
\text { \% change }\end{array}$ \\
\hline 13 & 625 & 670 \\
15 & 426 & 450 \\
16 & 495 & 420 \\
20 & 560 & 574 \\
23 & 65 & 51 \\
27 & 425 & 430 \\
33 & 201 & 220 \\
\hline
\end{tabular}

at $90^{\circ} \mathrm{C}$. plus or minus $4^{\circ}$ to constant weight and weighed on an analytical balance. The average ratio of dry matter to fresh matter was determined from a series of 10 experiments in which the tissue used was taken from the usual stock cultures. The range of the ratio of dry matter to fresh matter was from 6.2 per cent to 7.1 per cent with an average of 6.5 per cent. With the aid of the latter figure, changes in percentage of dry weight were easily calculated.

Cultures were closely observed for 4 days after preparation in order to determine whether any contaminants were present. When a contaminated piece of tissue was discovered, it was removed, weighed and its weight subtracted from the initial mass inoculum. The percentage of contamination was usually less than 1 per cent so that the effect on the final weight of the tissue was negligible.

The criteria of growth.-The accumulation of dry matter has sometimes not been considered to be a true index of growth since growth implies an increase in protoplasm as well as non-living dry matter (White, 1943). The increase in nitrogen content of the tissue is therefore considered by White to be a more precise index of growth. In order to determine whether there was a significant difference between accumulation of dry matter and total nitrogen, the total nitrogen content of the dry tissue of several experiments chosen at random was determined.

The tissue was digested with sulfuric acid and 30 per cent hydrogen peroxide at a temperature of $250^{\circ} \mathrm{C}$. The resultant solution was treated with Nessler's reagent and the color which developed was compared to a standard calibration curve by means of a Klett colorimeter.

The results (table 1) indicated a reasonable approximation between dry weight changes and total nitrogen changes. Because of this, it was decided that dry weight was a sufficiently accurate index of growth of the tissue and nitrogen determinations were discontinued.

Wet weight was determined along with dry weight since the differences between the two seem to shed some light on the significance of growth response of the tissue when subjected to different experimental conditions. These differences will be discussed further in the text where they are pertinent. 
TABLE 2. The effect of yeast extract

\begin{tabular}{lcc}
\hline \multicolumn{1}{c}{ Medium } & $\begin{array}{c}\text { Wet wt. } \\
\text { \% increase }\end{array}$ & $\begin{array}{c}\text { Dry wt. } \\
\% \text { increase }\end{array}$ \\
\hline $\begin{array}{l}\text { No extract } \\
\text { Autoclaved } \\
\text { extract, } 0.5 \%\end{array}$ & 69 & 45 \\
$\begin{array}{l}\text { Filtered } \\
\text { extract, } 0.5 \%\end{array}$ & 685 & 259 \\
\hline
\end{tabular}

EXPERIMENTAL RESULTS, - The growth curve.Three hundred vials of nutrient medium were selected and inoculated with explants of the tissue. Every 4 , days for a total of 24 days, the percentage increase in wet and dry weight was determined for 50 vials of tissue. The data are shown graphically in fig. $\mathrm{I}$.

The data indicate that maximum growth of the tissue is reached by the twentieth day. There is a lag phase of about 8 days before growth enters upon the exponential phase. Similar lag phases were obtained by Nickell and Burkholder (1950) for virus wound tumor tissue of Rumex and by Sternheimer (1953) for the same tissue as that used in the present investigation. Sternheimer observed maximum growth to occur after 32 days. However, after 20 days, the endosperm-derived tissue she used gained almost exactly the same weight as that described in this paper.

The effect of yeast extract.-The difficulty encountered in obtaining growth of the tissue on White's medium or uniform growth on White's medium supplemented by tomato juice initiated a search for a substance which would permit uniform and continuous growth of the tissue. In view of the efficacy of yeast extract in the maintenance of growth of various tissues and organs in vitro (Robbins, 1922; White, 1932, 1938; LaRue, 1936; Steeves and Sussex, 1952; Wetmore and Wardlaw, 1951), it appeared likely to be able to fulfill this role for maize tissue. Experiments were run with both the autoclaved and filtered material (table 2).

It was found that the filtered extract is almost twice as effective in promoting growth of the tissue as is the autoclaved. Because of this, filtered extract was used in all further experiments.

The effect of concentrations of yeast extract.-The need for yeast extract indicated that further trials should be made in order to determine the optimum concentration. Figure 2 shows the results.

The optimum concentration of yeast extract is about 0.5 per cent when growth is assessed on both wet and dry percentage increases. Below 0.5 per cent, the concentration of the extract appears to be limiting; above this concentration, the extract becomes inhibitory.

The effect of various carbon sources.-A survey of possible carbon sources was undertaken to determine which of the commonly encountered ones would permit optimum growth of the tissue. All were tested at the 2 per cent level. The data are summarized in table 3 .

Of the 10 carbon sources tested 5, lactose, galactose, arabinose, rhamnose, and glycerol permitted no growth at all; the tissue suffered a loss in weight.

The results obtained with starch were surprising as it has not been found to be utilized to any great extent when supplied as the only exogenous carbon source to tissue or organ cultures of green plants, except for two recent reports.

Nickell and Burkholder (1950) showed that the virus tumor tissue derived from sorrel grew on a medium which contained starch as the only carbohy. drate. Lampton (1952) who worked with the isolated endosperm of pawpaw obtained growth of the tissue when starch was present in the medium as the only carbon source.

In addition to 2 per cent starch, concentrations of 4 and 8 per cent were also used with maize tissue. The results were as follows: wet weight percentage increases were 424,731, and 897 respectively, and dry weight percentage increases were 302,625 , and 915 respectively.

There is a stimulation of growth with the higher concentrations of starch. The per cent increase at the 8 per cent level in dry weight exceeds that of the per cent increase in wet weight at the same concentration of starch. It would appear that the tissue was stimulated in its synthetic processes, but that water uptake from the medium was interfered with.

Sucrose, fructose, and glucose proved to be excellent carbon sources for the endosperm tissue. Their efficiency in supporting growth, however, varied, and was greatest for sucrose on a fresh weight basis and least for glucose. The latter sugar, however, permitted the greatest accumulation of dry matter. Since the percentage differences between the per cent dry weight increase between sucrose and glucose were small, it was decided to use sucrose as the standard carbon source because of its cheapness and ready availability in a pure state.

The determination of the optimum sucrose concentration.--A concentration series of sucrose was set up to determine the optimum concentration for the growth of the tissue. Figure 3 shows the data obtained.

An examination of the data reveals that below 2 per cent, the availability of sucrose is limiting. The optimum concentration as determined from these data is 2 per cent when assessed on a fresh weight basis. However, on a dry weight basis, 8 per cent sucrose is the best concentration. The greater the increase in sugar concentration, the greater is the ratio of dry weight to fresh weight. At the 2 highest concentrations, 8 and 12 per cent, the per cent increase in dry weight exceeds that of the increase in wet weight.

Street and Lowe (1950) found that the effect of 4 per cent sucrose in the inhibition of growth in length and production of laterals of excised tomato roots was not due to the osmotic pressure of the 

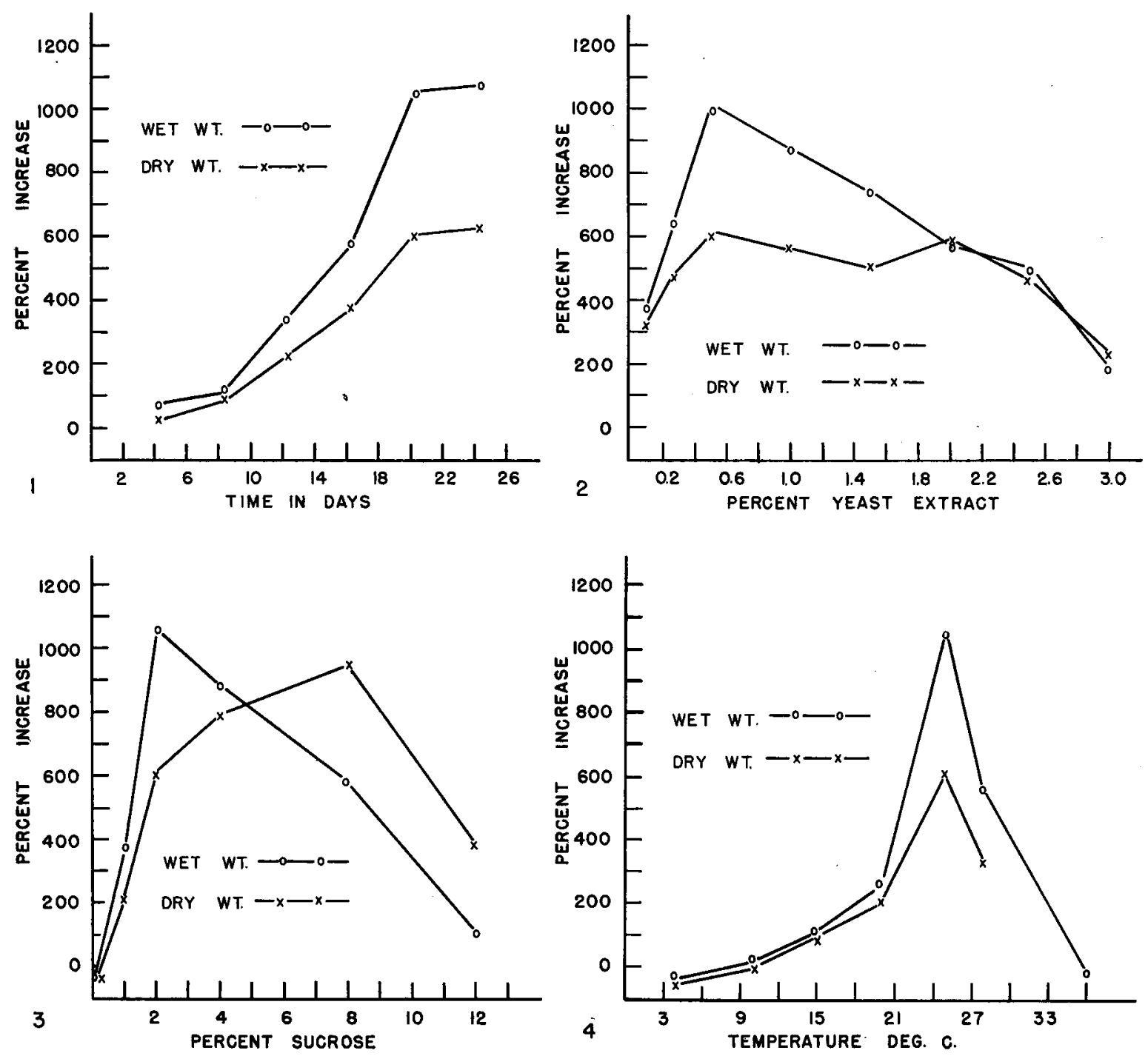

Fig. 1-4.-Fig. 1. The growth curve-Fig. 2. The effect of concentration of yeast extract on the growth of the tissue.-Fig. 3. The effect of concentration of sucrose on the growth of the tissue.-Fig. 4. The effect of temperature on the growth of the tissue.

medium. They used raffinose, a carbohydrate which these roots are unable to utilize, to adjust the osmotic pressure of media containing 1,2 , and 3 per cent sucrose to the osmotic value of 4 per cent sucrose. They found that, ". . . the deleterious effect of 4 per cent sucrose is not due to the enhanced O.P. of the medium but due to the concentration of sucrose itself. ... this suggests that high sucrose concentrations are deleterious to root growth because they derange the normal carbohydrate metabolism of the roots."

In an effort to determine whether the decrease in growth of the endosperm tissue at high sucrose concentrations was due to osmotic pressure or to an inherent toxicity of sucrose per se, a medium was prepared containing 2 per cent sucrose and 10 per cent lactose, a carbohydrate which the tissue is unable to utilize. This mixture should closely approximate the osmotic pressure of 12 per cent sucrose. The results showed the lactose-sucrose medium permitted about the same growth as did 12 per cent sucrose (lactose-sucrose: 106 per cent wet weight, 344 per cent dry weight; 12 per cent sucrose: 103 per cent wet weight, 386 per cent dry weight). Hence it appears that high sucrose concentrations interfere with the growth of endosperm tissue by virtue of an increased osmotic pressure and probably by disturbance of water uptake.

It is probable that there was not sufficient hydolysis of the lactose when autoclaved to permit the production of any utilizable sugars. Hydrolysis of lactose would yield one mole each of glucose and galactose. If any glucose were produced, the tissue would have shown some growth on the 2 
TABLE 3. The effect of various carbon sources

\begin{tabular}{lcc}
\hline Carbon source & $\begin{array}{c}\text { Wet wt. } \\
\% \text { increase }\end{array}$ & $\begin{array}{c}\text { Dry wt. } \\
\% \text { increase }\end{array}$ \\
\hline Sucrose & 1055 & 610 \\
Fructose & 989 & 560 \\
Glucose & 860 & 640 \\
Maltose & 690 & 505 \\
Starch & 425 & 302 \\
Lactose & 25 loss & 35 loss \\
Galactose & 52 loss & 63 loss \\
Arabinose & 56 loss & 42 loss \\
Rhamnose & 39 loss & 64 loss \\
Glycerol & 38 loss & \\
\hline
\end{tabular}

per cent lactose medium, but instead it revealed a loss in weight (table 3 ). A mixture of 1 per cent each of glucose and galactose permitted a wet weight increase of 230 per cent and tissue on 1 per cent glucose increased 171 per cent. It appears that there is some growth-promoting synergistic action between glucose and galactose in this tissue at least. The galactose used in this investigation was recrystallized from alcohol.

The effect of temperature.-Several investigations on the effects of temperature in relation to in vitro cultures have been made in an effort to determine the best temperature for optimum growth for a variety of tissues and organs (White, 1937a; van Overbeek et al., 1944; Slankis, 1949; Hurel-Py, 1950; Hildebrandt et al., 1945; Nickell and Burkholder, 1950).

To determine the optimum temperature for maize endosperm tissue, a series of experiments were performed in which the tissue was exposed to different temperatures for the growth period of 20 days. The temperature increments were limited by the available facilities and unfortunately the temperatures intermediate between $28^{\circ}$ and $36^{\circ} \mathrm{C}$. remain unexplored. In order to avoid excessive dehydration of the medium at $28^{\circ}$ and $36^{\circ}$, pans of water were placed in the incubators to raise the humidity.

The best temperature as determined from these trials is $25^{\circ} \mathrm{C}$. (fig. 4). There is almost a 50 per cent decrease in growth when the temperature is raised $3^{\circ}$. The difference in growth between the tissue exposed to $20^{\circ}$ and to $25^{\circ}$ is even more striking; there was more than four times the increase at the higher than at the lower temperature. This seems to indicate a great sensitivity of the tissue to temperature.

When the tissue which had been exposed to $4^{\circ}$ for 20 days had been removed to an environment of $25^{\circ}$, it resumed a growth rate which was nearly normal. As the tissue suffered a loss in weight at $4^{\circ}$, it must have continued to respire at that low temperature and, respiration, although at a greatly reduced rate, continued at the expense of reserve material in the cells.

The percentage loss in weight at $36^{\circ}$ was only 15 per cent; somewhat less than half that sustained by the tissue at $4^{\circ}$. This may indicate an inability to take up water at the higher temperature, and death of the tissue ensued shortly thereafter due to heat injury.

The effect of $p H$.- Investigations on the effects of different $\mathrm{pH}$ values on the growth of plant tissues grown in vitro are not very numerous. In most situations, the $\mathrm{pH}$ is not a critical factor as good growth of the tissues and organs takes place over the range of $\mathrm{pH}$ which are ordinarily encountered in nutrient media ( $\mathrm{pH}$ 4.5-6.3).

To determine the effects of initial $\mathrm{pH}$ upon the growth of the tissue, a graded series of media were prepared in which the range of $\mathrm{pH}$ tested was from $3.2-9.7$ in approximately unit increases.

Preliminary tests had shown that the $\mathrm{pH}$ of the complete medium was generally that of the yeast extract added. Thus, if yeast extract of $\mathrm{pH} 5.0$ was added to White's solution, the $\mathrm{pH}$ of which is about 6.0 , the $\mathrm{pH}$ of the final solution was 5.0 . In practice, the $\mathrm{pH}$ of the yeast extract solution was adjusted to the value desired with $\mathrm{HCl}$ or $\mathrm{KOH}$, Seitz-filtered and added to the rest of the medium. The $\mathrm{pH}$ of the final medium varied from one- to three-tenths of a $\mathrm{pH}$ unit from that of the adjusted values of the yeast extract.

The $\mathrm{pH}$ was determined with a Beckman model $\mathrm{G} \mathrm{pH}$ meter employing glass and calomel electrodes. The $\mathrm{pH}$ of the medium was determined both before and after growth of the tissue. In testing the $\mathrm{pH}$ of the agar, the media of several vials were homogenized with a few $\mathrm{ml}$. of distilled water, the electrodes were inserted and a reading was taken after 2 min. equilibration. The data are shown in fig. 5 .

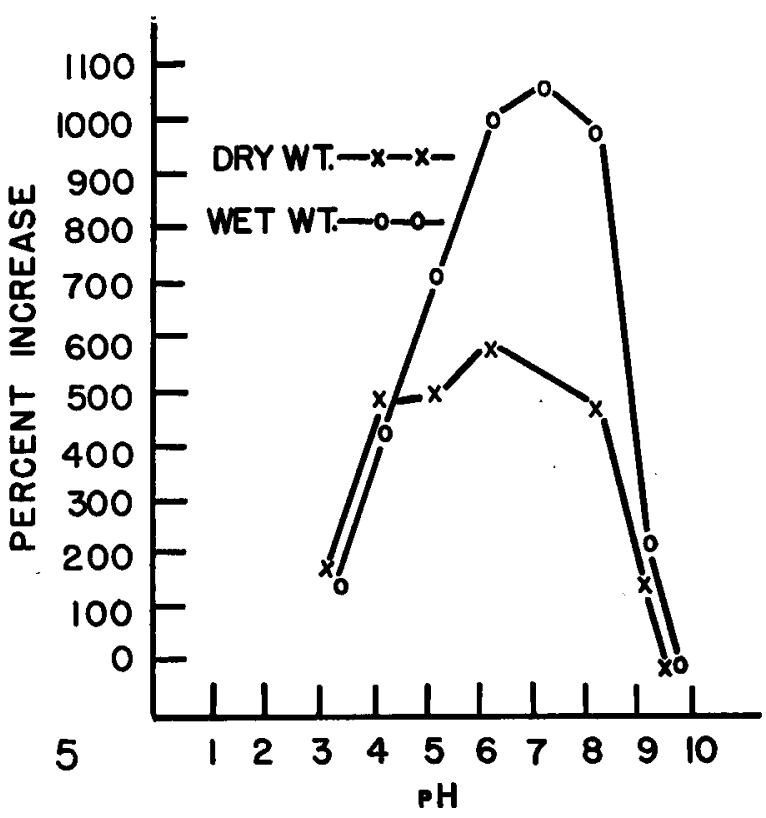

Fig. 5. The effect of initial $\mathrm{pH}$ on the growth of the tissue. 
A pH of 7.0 seems to support the best growth when assessed on a fresh weight basis. When determined on a dry weight basis, however, a $\mathrm{pH}$ of 6.1 appears to be optimum. The relatively smaller difference in percentage increase in fresh weight between the tissue grown at initial $\mathrm{pH} 6.1$ and $7.0(54)$ is probably not as significant as the difference in percentage increase in dry weight (91).

In general, the growth of the tissue was good over the range of 5.1-8.2 with an optimum between $\mathrm{pH} 6.1$ and 7.0.

The percentage increase in dry weight at $\mathrm{pH} 4.1$ and 8.2 are the same while the percentage increase in fresh weight at $\mathrm{pH} 8.2$ is more than twice that obtained at the lower $\mathrm{pH}$. In general, the ratio of dry weight decreases as the $\mathrm{pH}$ of the medium is increased. This may be due to an increase in the general permeability of the cell membranes due to decreased hydrogen ion concentration (Curtis and Clark, 1950).

The lowest limit of the $\mathrm{pH}$ scale at which the tissue can grow has not been determined. On the alkaline scale, however, a $\mathrm{pH}$ of 9.7 prevents the growth of "normal"-sized inocula. Gautheret $(1947 \mathrm{~b}, 1947 \mathrm{c})$ found that carrot tissue was killed at $\mathrm{pH} 2.8$ and in a medium "highly alkaline in which the $\mathrm{pH}$ was greater than 11.2."

Discussion.-A comparison of the effects of various chemical and physical environments on tissue cultures of maize endosperm with other tissue cultures reveals some similarities as well as differences. The high requirement for yeast extract ( $5 \mathrm{~g} . / \mathrm{l}$.) by the tissue is in great contrast to the concentrations (50-100 mg./l.) found to be optimum by other workers for many species of excised root tips (Robbins and White, 1936; White, 1932, 1934, 1937b). Steeves and Sussex (1952) have found $500 \mathrm{mg}$./l. to be best for the growth of fern callus as did Wetmore (Wetmore and Wardlaw, 1951) for excised stem apices. Lampton (1952) observed that $5 \mathrm{~g}$./l. of yeast extract and higher concentrations were inhibitory to the growth of pawpaw endosperm cultures and finally resulted in extreme blackening and the death of the tissue.

Preliminary experiments performed in an attempt to elucidate the factors responsible for growth promotion in the extract indicate the beneficial action of the complex may in part be replaced by comparatively high concentrations of casein hydrolysate or a less complex mixture of 5 amino acids which resulted in a completely synthetic medium. Nevertheless, on media containing casein hydrolysate or the amino-acid mixture, the growth of the tissue was only about one-third of that attained on the yeast extract medium. It is apparent then that yeast extract contains one or more essential metabolites or nutrilites other than amino acids necessary for optimum growth of the maize endosperm tissue cultures.

The fact that the tissue grows at all on a com- pletely synthetic medium indicates that the substances other than amino acids in yeast extract are not essential in the sense that they represent an absolute requirement without which growth is not possible. Rather, it suggests that the tissue can synthesize these substances, but only very slowly or to a limited degree.

Further experiments are now in progress to determine more fully the growth factors present in yeast extract which permit growth of the tissue. It is hoped that the results of this investigation will be reported in the near future.

Another point of contrast with most other tissue cultures is the ability of the tissue to utilize starch when it is supplied as the only carbon source in the medium. Robbins (1918), Gautheret (1945), and Hildebrandt and Riker (1949) tested starch on a variety of tissue and organ cultures of green plants and found that very little or no growth took place. Two exceptions to this are the Rumex virus tumor tissue (Nickell and Burkholder, 1950) and the endosperm tissue of Asimina (Lampton, 1952).

Brakke and Nickell (1951) have demonstrated the excretion of an alpha-amylase by the Rumex tissue into the culture medium when starch was the only exogenous carbon source. It is not certain whether this also occurs in cultures of endospermderived tissue. There is no basis, however, to assume that the starch enters the cells from the medium. Evidence presented by Brakke and Nickell as well as the better known examples of extracellular digestion of starch by microorganisms does not warrant the postulation of another hypothesis.

The explanation for the increased ratio of dry matter to wet matter produced by the tissue when grown on successively higher concentrations of starch may be twofold. It does not seem reasonable that the osmotic pressure of the medium was raised sufficiently by the higher concentrations of starch to seriously impair water uptake. It is possible, however, that the enzymes which were excreted into the medium by the tissue may have degraded all or most of the starch to maltose or glucose and thereby raised the osmotic pressure of the medium so seriously as to disturb water uptake. This hypothesis would have to assume a stimulating action on enzyme excretion caused by higher substrate concentrations. Another possibility is that the starch may have bound water in the medium because of its colloidal properties so that water became physiologically unavailable to the tissue.

In common with most other tissue cultures, maize endosperm tissue was unable to utilize galactose, lactose, rhamnose, arabinose, or glycerol as carbon sources. There are several factors which may be responsible. For example, these substances may not penetrate into the tissues. McCready and Hassid (1941) have demonstrated the potentiality of sucrose synthesis by barley shoots from various other carbohydrates once the tissues were properly infiltrated with solutions of these compounds. 
Another possibility is a lack of the proper enzymes by the tissue. Burström (1948) was able to show that although galactose was respired by excised wheat roots, no growth took place which indicated that galactose did not contribute to the synthetic processes of the cells.

The preferential utilization of sucrose over fructose and glucose has been noted in many tissue cultures including maize endosperm tissue and has presented a paradox until recently. Dormer and Street (1949) and Street and Lowe (1950) were able to show that free glucose was not taken up by excised tomato roots. However, when sucrose was supplied as the carbon source, the sucrose was phosphorylated at the surface membranes of the root cells, and the glucose moiety entered the cells as hexose phosphate. A residue of fructose was left in the medium. Hence, it appears that sucrose is preferentially used because of the ease with which it is phosphorylated. Van Overbeek and his coworkers (1944) observed that sucrose was superior to glucose in supporting the growth of excised Datura embryos and suggested a mechanism similar to that postulated by Street and Lowe, although no experimental evidence was presented to support this view.

\section{SUMMARY}

A tissue derived from the endosperm of maize has been successfully grown in vitro and exhibits the property of unlimited growth. Some of the requirements for the growth of the tissue under culture conditions have been determined. These are: a mineral salt medium containing 2 per cent sucrose and 0.5 per cent Seitz-filtered yeast extract. An initial $\mathrm{pH}$ of 6.1-7.0 provides for optimum growth as does a temperature of $25^{\circ} \mathrm{C}$. The tissue is able to utilize starch as the sole exogenous carbon source. The high requirement for yeast extract suggests a high organic nitrogen requirement. Preliminary tests with casein hydrolysate and mixtures of amino acids have shown that the beneficial action of yeast extract may in part be replaced by amino acids. Thus, the extract supplies some substance or substances other than amino acids necessary for the optimum growth of the tissue.

\section{DEPaRTMENT OF Botany, \\ UNIVERSITY OF Michigan, \\ ANn ARBor, Michigan}

\section{LITERATURE CITED}

BaLl, E. 1950. Differentiation in callus cultures of Sequoia sempervirens. Growth 14: 295-325.

—. 1953. Studies of the accumulation of certain radio-isotopes by a callus culture. Amer. Jour. Bot. 40: 306-316.

Brakke, M. L., aNd L. G. Nickell, 1951. Secretion of alpha-amylase by Rumex virus tumors in vitro. Arch. Biochem. Biophys. 32: 28-41.

BuRström, H. 1948. Observations on the influence of galactose on wheat roots. Physiol. Plant. 1: 209-215.

Curtis, O. F., and D. G. Clark. 1950. An introduction to plant physiology. McGraw-Hill Co. New York.

Curtis, J. T., and M. A. Nichol. 1947. Culture of proliferating orchid embryos in vitro. Bull. Torrey Bot. Club 75: 358-373.

Dormer, K. J., and H. E. Street. 1949. The carbohydrate nutrition of tomato roots. Ann. Bot. N.S. 13: 199-217.

Gautheret, R. J. 1945. La culture des tissus. Grevin, Lagny-sur-Marne.

- 1947a. Plant tissue culture. Growth (Supplement Sixth Growth Symposium) 10: 21-43.

- 1947b. $\mathrm{pH}$ et culture de tissus végétant. Rev. Gén. Bot. 54: 5-34.

—. 1947c. Action du pH sur le développement des cultures de tissus de carotte. Compt. Rend. Soc. Biol., Paris 14l: 25.

Hurel-Py, Germaine. 1950. Recherches préliminaries sur la culture aseptique des prothalles de filicinées. Rev. Gén. Bot. 57: 637-722.

Hildebrandt, A. C., and A. J. Riker. 1949. The influence of various carbon compounds on the growth of marigold, Paris-daisy, periwinkle, sunflower, and tobacco tissue in vitro. Amer. Jour. Bot. 36: 74-85.

$\longrightarrow$, AND B. M. Duggar. 1945. Growth in vitro of excised tobacco and sunflower tissue with different temperatures, hydrogen-ion concentrations, and amounts of sugar. Amer. Jour. Bot. 32: 357-361.
Lampton, R. K. 1952. Developmental and experimental morphology of the ovule and seed of Asimina triloba Dunal. Thesis. Univ. Michigan. Ann Arbor.

LARue, C. D. 1936. The growth of plant embryos in culture. Bull. Torrey Bot. Club. 63: 365-382.

-1 1947. Growth and regeneration of the endosperm of Maize in culture. Amer. Jour. Bot. 34: 585.

- - 1949. Cultures of the endosperm of maize. Amer. Jour. Bot. 36: 798.

Lowenberg, J. R., and F. Skoog. 1952. Pine tissue cultures. Physiol. Plant. 5: 33-36.

McCready, R. M., AND W. E. Hassrd. 1941. Transformation of sugars in excised barley shoots. Plant Physiol. 16: $599-610$.

Morel, G., and R. H. Wetmore. 1951a. Tissue cultures of monocotyledons. Amer. Jour. Bot. 38: 138-140.

$\longrightarrow$ AND $\longrightarrow$ 195Ib. Fern callus tissue culture. Amer. Jour. Bot. 38: 138-140.

Nickell, L. G., AND P. R. BuRkholder. 1950. Atypical growth of plants. II. Growth in vitro of virus tumors of Rumex in relation to temperature, $\mathrm{pH}$, and various sources of nitrogen, carbon, and sulfur. Amer. Jour. Bot. 37: 538-547.

Nitsch, J. P. 1951. Growth and development in vitro of excised ovaries. Amer. Jour. Bot. 38: 566-577.

RoBBINs, W. J. 1918. Direct assimilation of organic carbon by Ceratodon purpureus. Bot. Gaz. 65: 543-551.

- 1 1922. Cultivation of excised root tips and stem tips under sterile conditions. Bot. Gaz. 73: 376-390.

_- AND Virginia B. White. 1936. Limited growth and abnormalities in excised corn root tips. Bot. Gaz. 98: 209-242.

Slankis, V. 1949. Einfluss der Temperatur auf das Wachstum der isolierten Wurzeln von Pinus sylvestris. Physiol. Plant. 2: 131-137.

Steeves, T. A., AND I. M. Sussex. 1952. In vitro cultures of a fern callus. Nature 170: 672 . 
Sternheimer, Elizabeth P. 1953. Effects of X-irradiation on the growth of certain plant tissues in vitro. Thesis. Univ. Michigan. Ann Arbor.

Street, H. E., and J. S. Lowe. 1950. The carbohydrate nutrition of tomato roots. II. The mechanism of sucrose absorption by excised roots. Ann. Bot. N.S. 16: 185-205.

Tulecke, W. R. 1953. A tissue derived from the pollen of Ginkgo biloba. Science 117: 599-600.

Van Overbeek, J., R. Siu, and A. J. Haagen-Smrt. 1944. Factors affecting the growth of Datura embryos in vitro. Amer. Jour. Bot. 31: 219-224.

WetMore, R. H., and G. Morel. 1951a. Sur la culture in vitro de prothalles de Lycopodium cernuum. Compt. Rend. Acad. Sci. Paris 233: 323-324.

-, AND _ _ . 195lb. Sur la culture du gamétophyte de Sélaginelle. Compt. Rend. Acad. Sci. Paris 233: $430-431$.
AND C. W. WardLaW. 1951. Experimental morphogenesis in vascular plants. Ann. Rev. Plant Physiol. 2: 269-292.

White, P. R. 1932. Influence of some environmental conditions on the growth of excised root tips of wheat seedlings in liquid media. Plant Physiol. 7: 613-628.

1934. Potentially unlimited growth of excised tomato root tips in a liquid medium. Plant Physiol. 9: $586-600$.

- 1937a. Survival of isolated tomato roots at suboptimal and supraoptimal temperatures. Plant Physiol. 12: 771-776.

- 1937b. Separation from yeast extract of materials essential for growth of excised tomato roots. Plant Physiol. 12: 777-791.

1938. Cultivation of excised roots of dicotyledonous plants. Amer. Jour. Bot. 25: 348-356.

1943. A handbook of plant tissue culture. Ronald Press Co. New York. 